\title{
FEATURE Application of monitoring to inform policy and programs and achieve water quality goals
}

\author{
Lisa F. Duriancik, Katie Flahive, and Deanna Osmond
}

W ater quality monitoring is used throughout the world to assess the quality of water resources. Data and analyses from assessments can be used to inform policy as well as program design, delivery approaches, practice design, and adaptive management to enhance outcomes. Many of these assessments have demonstrated problems associated with nutrient enrichment and sedimentation of water resources (Chapman 1996; Dubrovsky and Hamilton 2010; Scott and Gemmell 2013). Not surprisingly, because of its land area and necessary inputs to support food production services, agriculture can be a major source of nutrients and sediment (USEPA 2008), contributing to the impairment of water resources across the globe. Key water quality monitoring programs to document large-scale water quality status or trends exist. These are useful for tracking changes in water resource condition and trends over time in basins or large water bodies, but are often not fine enough resolution alone to attribute effects to specific actions or understand the processes occurring or being influenced by management.

Water quality monitoring can also be used to document the effectiveness of agricultural conservation practices at both the field and watershed scale. There is a significant body of edge-of-field and plot research documenting reductions from diverse practices ranging from conservation tillage to nutrient management to exclusion fencing (Schnepf and Cox 2006). Edge-of-field and/or plot research to document conservation practice effectiveness includes a wide range of responses, demonstrating $100 \%$ to negative nutrient and sediment reductions (Edgell et al. 2015; Gagnon et al. 2004, 2008; King et al. 2016; Line et al. 2016; Richards and

Lisa F. Duriancik is a natural resources specialist, USDA Natural Resources Conservation Service, Resource Assessment Division, Beltsville, Maryland. Katie Flahive is an environmental scientist, US Environmental Protection Agency, Washington, DC. Deanna Osmond is a professor in crop and soil sciences, North Carolina State University, Raleigh, North Carolina.
Baker 2002; Sharpley et al. 2006; Shepard 2005; Smith et al. 2006). Edge-of-field scale research also develops understanding of biophysical processes and of how conservation practices or management influence (or change) processes (Williams et al. 2016) Evaluation of conservation practices over time documents their effectiveness, reduces uncertainty in management options, and enables development of innovative solutions to complex water quality challenges.

Documenting water quality change at the watershed scale has proven more challenging than plot or field-scale studies because of the numerous factors that cumulatively influence parameters, as demonstrated by a number of federal programs that work to relate conservation with water quality change at a watershed level (Dressing et al. 1983; Gale et al. 1993; Morrison and Lake 1983; Osmond et al. 2012; Spooner et al. 2011). Examples of federal programs funded by the US Department of Agriculture (USDA) and the US Environmental Protection Agency (USEPA), with the involvement of many local partners, include the following: the Black Creek Project in northeastern Indiana (Morrison and Lake 1983), Hydrologic Unit Area and the Demonstration Projects (Meals and Sutton 1996), the Model Implementation Program (Dressing et al 1983), the Rural Clean Water Program (Gale et al. 1993), USDA Management Systems Evaluation Area Program (Ward et al. 1994); USEPA Section 319 National Nonpoint Source Monitoring program (Spooner et al. 2011; USEPA 2016), and more recently the USDA Conservation Effects Assessment Project (CEAP) Watershed Assessment Studies (Duriancik et al. 2008; Osmond et al. 2012; Tomer et al. 2014).

Water quality monitoring should be designed based on the purpose for which it is intended. For example, specific questions should be established prior to determining the appropriate monitoring design (Davenport 2003; Dressing and Meals 2005; Dressing et al. 2016; IGTF 1995; Meals et al. 2012; MPCA 2003; Olsen and Robertson 2003; USDA NRCS 2003, 2012a, 2012b; USEPA 1997, 2006; Ward et al. 1990). These questions include identifying water quality or resource problems, assessing permit compliance, developing total maximum daily loads and pollutant load allocations, analyzing national or statewide trends, assessing water quality impacts of management and conservation practices, calibrating or validating water quality models, implementing water quality trading, and understanding pollutant sources and transport.

\section{ADDRESSING CHALLENGES IN WATERSHED-SCALE NONPOINT SOURCE MONITORING}

Regardless of the type of water quality monitoring conducted, goals and objectives must be set before establishing the water quality monitoring protocol. Water quality monitoring decisions then must be based on project goals and objectives, after which the monitoring design can be established.As part of this design, the scale and frequency of the monitoring must be determined. In addition, response variable data must also be collected. Interpretation of data can be challenging due to lag times for many water resources to demonstrate improvement (Meals et al. 2010; Van Meter et al. 2016). Then there are the technical aspects of collecting, processing, and analyzing data, while ensuring adequate quality control.

Discerning water quality changes from conservation practices is feasible with care in site selection, land use tracking, and water quality monitoring design. With careful project design and long-term efforts, changes in water quality as a result of conservation have been documented at the watershed scale (Osmond et al. 2012; Lizotte et al.2014). Monitoring design must incorporate explanatory variables: weather data, stream bank assessment, nature and extent of adopted conservation practices, and other changes driven by conservation implementation. Scale, frequency, type, and location of monitoring will vary based on many factors including layout and characteristics of watershed, location of fixed monitoring stations, amount and distribution of conservation practices, and critical source areas in the watershed. 
Lessons learned from national projects assessing water quality change due to conservation practice adoption at the watershed scale have shown the difficulties associated with these projects (Dressing et al. 1983; Morrison and Lake 1983; Gale et al. 1993; Jackson-Smith and McEvoy 2011; Spooner et al. 2011), including recent CEAP watershed assessment studies (Osmond et al. 2012; Tomer and Locke 2011). Water quality monitoring is technically difficult and expensive; in order to utilize limited monitoring funding resources effectively, most watershed conservation implementation projects should not conduct water quality monitoring to demonstrate the effectiveness of conservation practices (Meals et al. 2012) unless the aforementioned water quality monitoring conditions are met. That does not preclude other types of monitoring. However, where paired watershed monitoring designs developed during the Rural Clean Water Program (Gale et al. 1993; Spooner and Line 1993) have been used in USEPA programs (Lombardo et al. 2000; USEPA 2016) and CEAP projects (Osmond et al. 2012), monitoring has been able to be used to document watershed-scale conservation effects. The USDA Natural Resources Conservation Service used lessons learned from USEPA, USDA Agricultural Research Service CEAP, and USDA National Institute of Food and Agriculture CEAP to design their edge-of-field water quality monitoring conservation activity (USDA NRCS 2012a, 2012b), which mimics the paired watershed design, but at field scale, and provides stringent guidelines for both water quality and land treatment data collection.

Further, when trying to use water quality monitoring to associate cause and effect at a watershed scale, no matter how rigorous the water quality monitoring, it will be impossible to link observed changes in water quality to land treatment without equally rigorous conservation and land management information (Gale et al. 1993; Meals et al. 2012). Data on farm management (e.g., split application of nutrients) is essential and often extremely difficult to obtain compared to structural, visible practices. Also, in long-term monitoring, where management or installed structural practices may require time to become fully effective, degrade, are modified, or abandoned, these changes, in addition to simultaneous land use changes, make interpretation of monitoring results difficult (Jackson-Smith et al. 2010). This data is rarely obtained (Gale et al. 1993; Meals et al. 2012), however, due to privacy or time required to get detailed information from operators, and represents a gap in current literature.

Given challenges with water quality monitoring discussed above, with regards to documenting conservation effects and informing policy and programs, it is helpful when results are presented that include supporting information about why or why not effects were documented. It is often the case that one or some of the challenges discussed above influenced ability to document effects. And, for decision makers, particularly those without monitoring experience, communicating the factors that affected ability to observe results is helpful in putting the findings into context. For example, lessons learned have highlighted that often if an effect of conservation cannot be detected, it may be due to a limitation of the monitoring plan or implementation status in the field or watershed, not that the practices are not or will not be effective at some point. Therefore, communicating the nuances about the limitations of monitoring in that project, as well as the supporting information regarding the effects measured, is very important with regards to water quality monitoring data being used accurately to inform policy or programs.

Water quality monitoring is a tool. For the purposes of documenting water quality effects of conservation at a watershed scale, it is often most useful in combination with appropriate, well-selected, and technically strong modeling approaches (Easton et al. 2008; Arabi et al. 2012). It cannot substitute for (1) conducting watershed planning, (2) determining appropriate conservation practices, (3) determining critical source areas, (4) identifying watershed farmers' attitudes toward conservation practices, (5) maintaining conservation practices, and (6) providing financial and technical assistance. Water quality monitoring can be used for (1) watershed planning and implementation to identify pollutant(s) of concern, sources, and hydrologic transport; (2) designing new conservation practice standards;
(3) documenting conservation practice effectiveness; (4) evaluating long-term or life-span conservation practice operation and maintenance to maintain effectiveness; (5) informing future management decisions; (6) providing information for outreach and adaptive management; and (7) tracking progress towards a goal.

\section{WHO NEEDS WATER QUALITY DATA AND WHY}

Data users are varied, and all may have different questions that need answers. Data users can include producers; farm managers; advisors; conservation implementers or contractors; watershed planners and managers; federal, state, and local program managers; policy makers; and those that improve technologies including agencies, scientists, and researchers (figure 1). This broad user universe means that although there is much water quality data collected, not all data are collected to answer the same question nor is it all of the same quality. Researchers and statisticians can dig into broad sets of data when compiled to identify questions that can be answered, but that may not always drive a user to a valuable outcome.

Given the range of data collectors and monitoring objectives, there is also potential for a range of data quality to be generated. Data collected for some project needs may meet individual project objectives, but may not necessarily be useful in a broader context or for more rigorous requirements, as variables may not be reported in equal manner. For example, data collected to support adaptive management at field scale would provide more immediate feedback to managers of operations in that field, but would not necessarily be adequate to answer questions where scale (temporal and spatial), replication, rigor, and reliability of data are most certainly considerations. New innovations in monitoring techniques and equipment (i.e., sensors) could be useful in improving the quality, frequency, and intensity of sampling at several scales in the future, but their use under seasonal and long-term conditions, calibration, and maintenance must be considered. Efforts like the Federal Nutrient Sensor Challenge are vital to developing these alternate approaches, potentially expanding coverage, and driving down future monitoring cost. 


\section{Figure 1}

Examples of the range of water quality data users and their uses.

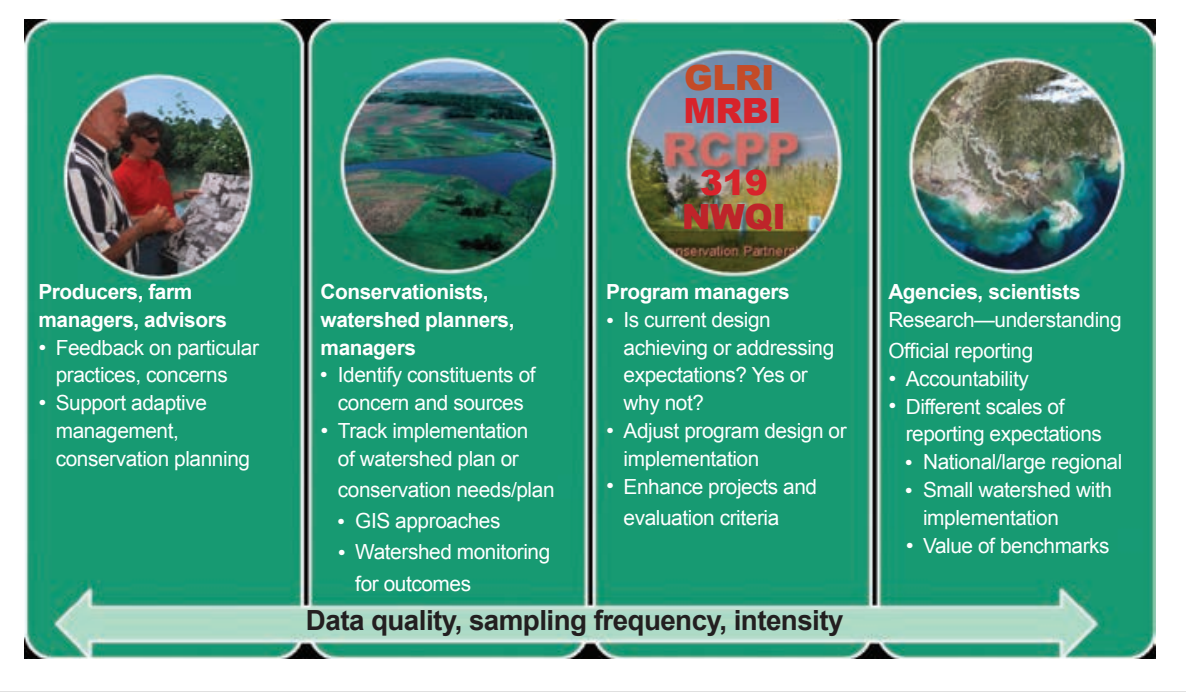

WATER QUALITY DATA: COORDINATION AND COLLABORATION

Because monitoring is conducted for a range of uses and objectives, often reflecting a limited mission or purview of an organization, there is a need for data collectors and users to better coordinate. Improved coordination of water quality monitoring collection is vital and often necessary where multiple sources and thus multiple entities are partnering together to address watershed needs. Coordination of monitoring with similar objectives can support better documentation of conservation outcomes and watershed changes at a range of scales, for example, within a field, at the edge of a field, within the stream in a subwatershed, and at the watershed outlet. It may be possible, with better planning, to design data collection to address organizational objectives while also collecting data that is of broader use as part of larger datasets to answer related questions.

Good communication and coordination among partners doing monitoring and stakeholders within a watershed or basin could enable compilation of data to support broader scale analyses, collection of data to answer related questions, as well as modeling to better understand and attribute effects. High-quality monitoring data across small watersheds is often not currently broadly available, which is one factor limiting model application regionally and nationally at smaller scales. Strategically aligning conservation implementation with monitoring capacity or infrastructure requires close partner and stakeholder coordination and has often proven difficult; therefore it remains a challenge to better measurement of conservation effects. More coordinated, comprehensive monitoring scales and designs, and more strategic alignment of monitoring and practice implementation would enable better synthesis in the future and feedback into field-scale, watershed, and programmatic-level adaptive management for improved water quality outcomes.

\section{REDUCING NONPOINT SOURCES NEEDS}

\section{A WATERSHED PLANNING FOCUS}

As mentioned, the key to good monitoring results is the upfront identification of the problem and defined questions the monitoring is being designed to answer. In watershed projects, monitoring is a tool that can be an indicator of watershed restoration, source measurement, and pollution identification. It is one part of an overall watershed planning process that should be used to restore and protect the land and water resources.

At the watershed scale, the Clean Water Act Section 319 National Nonpoint Source Program provides financial assistance to states to manage a state-wide program. Where 319 funds are to be used for watershed projects, a nine-element watershed plan must be in place to allow for locally led efforts to drive nutrient load reductions. From USEPA's guidance:

For many years EPA has focused $\mathbb{} \ 319$ resources on watershed-based environ- mental restoration and protection, in which local stakeholders join forces to develop and implement watershed based plans to address nonpoint source pollution based on the particular conditions in their communities. The watershed approach is a coordinating framework to organize public and private sector efforts to identify, prioritize, and then implement activities to address water-related problems (considering both surface and ground water). This approach is commonly characterized by diverse, well-integrated partnerships; a specific geographic focus action driven by environmental and public health objectives and by strong science and data; and coordinated priority setting and integrated solutions. (USEPA 2013)

Due to the complex and diffuse nature of nonpoint source pollution, the substantial costs to address it, and frequent reliance on voluntary action by individual landowners, successfully addressing nonpoint source pollution to achieve water quality standards often requires years of support from a coalition of stakeholders, programs, and funding sources. Watershed-based planning helps address water quality problems in a holistic manner by fully assessing the potential contributing causes and sources of pollution, then prioritizing restoration and protection strategies to address these problems. In adopting the watershed approach over the past several years, state nonpoint source programs have demonstrated their capability to solve nonpoint source pollution problems. Most of the Section 319 success stories document that multiyear, watershedwide collaborations were required to deliver success. (USEPA 2013).

A watershed plan will identify critical areas, pollutant sources, loads, potential management practices, etc. To reduce impacts from agricultural lands, conservation implementation must be focused in targeted watersheds with critical areas identified. As discussed previously, the science is confirmed: targeting systems of conservation practices in the right places is essential to water quality results and effective return for investment. Welldesigned water quality monitoring is needed to inform those contributing to efforts to improve the quality of water resources in their watershed and downstream receiving water bodies for success. 


\section{CONCLUSION}

Given the time it can take to achieve observable improvements in watershed water quality, long-term monitoring in benchmark projects, well designed to detect effects, is key to informing stakeholders involved in the efforts. Ongoing efforts like the CEAP Watershed Assessment Studies, which involve many partners, provide good examples of efforts specifically designed to address this challenge. Likewise, smaller scale subwatershed and edge-of-field monitoring is also valuable as earlier feedback on water quality outcomes from often voluntary conservation efforts, to support continued stewardship and additional conservation adoption when management needs to be adapted. Efforts by conservationists to track conservation practice implementation spatially and temporally, relative to known critical source areas and soil vulnerabilities as defined in a watershed assessment or plan, are highly recommended, given the time it takes to achieve conservation system implementation, lag time, program reporting needs, and ability to communicate efforts and support continued voluntary adoption of effective conservation practices. Such information on progress toward implementation goals in a watershed plan is also useful to support interpretation of water quality monitoring data (where available), as well as an interim indicator of progress toward measureable water quality changes.

\section{DISCLAIMER}

Any opinions, findings, conclusions, or recommendations expressed in this publication are those of the author(s) and do not necessarily reflect the view or policies of the USDA, which is an equal opportunity provider and employer. The USDA is an equal opportunity provider and employer. Any use of trade, firm, or product names is for descriptive purposes only and does not imply endorsement by the US Government.

This work is not a product of the US Government or the USEPA. The author is not doing this work in any governmental capacity. The views expressed are her own and do not necessarily represent those of the US or USEPA.

\section{REFERENCES}

Arabi, M., D. Meals, and D. Hoag. 2012. Watershed modeling in the NIFA-CEAP projects. In How to Build Better Agricultural Conservation Programs to Protect Water Quality: The National Institute of Food and Agriculture-Conservation Effects Assessment Project Experience, eds. D. Osmond, D. Meals, D. Hoag, and M. Arabi. Ankeny, IA: Soil and Water Conservation Society.

Chapman, D. (ed). 1996. Water Quality Assessments-A Guide to Use of Biota, Sediments and Water in Environmental Monitoring, 2nd Edition. United Nations Educational Scientific and Cultural Organization/World Health Organization/United Nations Environment Program. Cambridge, UK: University Press.

Davenport,T.E.2003.TheWatershed Project Management Guide. Boca Raton, FL: Lewis Publishers.

Dressing, S.A., J.M., Kreglow, R.P. Maas, F.A. Koehler, FJ. Humenik, and W.K. Snyder. 1983. The Model Implementation Program: Lessons Learned from Agricultural Water Quality Projects. Washington, DC: USDA and US Environmental Protection Agency.

Dressing, S.A., and D.W. Meals. 2005. Designing water quality monitoring programs for watershed projects, Tech Notes 2, July 2005. Developed for US Environmental Protection Agency by Tetra Tech, Inc. Fairfax, VA: Tetra Tech, Inc. https:// www.epa.gov/sites/production/files/2015-10/ documents/technote2_wq_monitoring.pdf.

Dressing, S.A., D.W. Meals, J.B. Harcum, J. Spooner, J.B. Stribling, R.P. Richards, C.J. Millard, S.A. Lanberg, and J.G. O'Donnell. 2016. Monitoring and Evaluating Nonpoint Source Watershed Projects. EPA 841-R-16-010. Washington, DC: US Environmental Protection Agency. https:// www.epa.gov/sites/production/files/2016-06/ documents/nps_monitoring_guide_may_2016combined_plain.pdf.

Dubrovsky, N.M., and P.A. Hamilton, 2010. Nutrients in the Nation's streams and groundwater: National Findings and Implications: US Geological Survey Fact Sheet 2010-3078. Reston, Virginia: US Geological Survey. http://pubs.usgs.gov/ fs/2010/3078/pdf/fs20103078.pdf.

Duriancik, L.F., D. Bucks, J.P. Dobrowolski, T. Drewes, S.D. Eckles, L. Jolley, R.L. Kellogg, D. Lund, J.R. Makuch, M.P. O’Neill, C.A. Rewa, M.R. Walbridge, R. Parry, and M.A. Weltz. 2008. The first five years of the Conservation Effects Assessment Project. Journal of Soil and Water Conservation 63(6):185A-188A, doi:10.2489/ jswc.63.6.185A.

Easton, Z.M., M.T. Walter, and T.S. Steenhuis. 2008. Combined monitoring and modeling indicate the most effective agricultural best management practices. Journal of Environmental Quality 37:1799-18009, doi:10.2134/jeq2007.0522.

Edgell, J., D.L. Osmond, D.E. Line, G. Hoyt, J.M. Grossman, and E.M. Larsen. 2015. Comparison of surface water quality and yields from organically and conventionally produced sweet corn plots with conservation and conventional tillage. Journal of Environmental Quality 44:1-10, doi:10.2134/jeq2015.02.0074.

Gagnon, S.R., J.R. Makuch, and C.Y. Harper. 2008. Effects of Agricultural Conservation Practices on Fish and Wildlife: A Conservation Effects Assessment Project (CEAP) Bibliography. Special Reference Briefs Series no. SRB 200801. Beltsville, MD: Water Quality Information Center, National Agricultural Library, USDA Agricultural Research Service.

Gagnon, S.R., J.R. Makuch, and T.J. Sherman. 2004. Environmental Effects of US Department of Agricultural Conservation Programs: A Conservation Effects Assessment Project (CEAP) Bibliography. Special Reference Briefs Series no. SRB 2004-01. Beltsville, MD: Water Quality Information Center, National Agricultural Library, USDA Agricultural Research Service.

Gale, J.A., D.E. Line, D.L. Osmond, S.W. Coffey, J. Spooner, J.A. Arnold, T.J. Hoban, and R.C. Wimberley. 1993. Evaluation of the Experimental Rural Clean Water Program. EPA-841-R-93-005. Raleigh, NC: National Water Quality Evaluation Project, Water Quality Group, Biological and Agricultural Engineering Department, North Carolina State University.

IGTF (Intergovernmental Task Force on Monitoring Water Quality). 1995. Final Report of the Intergovernmental Task Force on Monitoring Water Quality. US Geological Survey Open-File Report 95-742. Reston,VA: US Geological Survey. https://pubs.usgs.gov/of/1995/0742/report.pdf.

Jackson-Smith, D.B., M. Halling, E. de la Hoz, J.P. McEvoy, and J.S. Horsburgh. 2010. Measuring conservation program best management practice implementation and maintenance at the watershed scale. Journal of Soil and Water Conservation 65(6):413-423, doi:10.2489/jswc.65.6.413.

Jackson-Smith, D.B. and J.P. McEvoy. 2011. Assessing the long-term impacts of water quality outreach and education efforts on landowners in the Little Bear River Watershed in northern Utah. Journal of Agricultural Education and Extension 17(4):341-354.

King, S.E., D.L. Osmond, J. Smith, M.R. Burchell, M. Dukes, R.O. Evans, S. Knies, S. Kunickis. 2016. Effects of riparian buffer vegetation and width: A 12-year longitudinal study. Journal of Environmental Quality 45(4):1243-1251, doi:10.2134/jeq2015.06.0321.

Line, D.E., D.L. Osmond, and W. Childres. 2016. Effectiveness of livestock exclusion in a pasture of central North Carolina. Journal 
of Environmental Quality doi:10.2134/jeq2016.03.0089.

Lizotte, R.E., Jr., S.S. Knight, M.A. Locke, and R.L. Bingner. 2014. Influence of integrated watershedscale agricultural conservation practices on lake water quality.Journal of Soil and Water Conservation 69(2):160-170, doi: 10.2489/jswc.69.2.160.

Lombardo, L.A., G.L. Grabow, J. Spooner, D.E. Line, D.L. Osmond, and G.D. Jennings. 2000. Section 319 Nonpoint Source National Monitoring Program Successes and Recommendations. Raleigh, NC: Water Quality Group, Biological and Agricultural Engineering Department, North Carolina State University. https://www.epa.gov/sites/production/ files/2015-10/documents/nmp_successes.pdf.

Meals, D.W., S.A. Dressing, and T.E. Davenport. 2010. Lag time in water quality response to best management practices: A review. Journal of Environmental Quality 39:85-89.

Meals, D.W., D.L. Osmond, J. Spooner, and D.E. Line. 2012. Water quality monitoring: NIFA-CEAP projects. In How to Build Better Agricultural Conservation Programs to Protect Water Quality: The National Institute of Food and AgricultureConservation Effects Assessment Project Experience, ed. D. Osmond, D. Meals, D. Hoag, and M. Arabi. Ankeny, IA: Soil and Water Conservation Society.

Meals, D.W., and J.D. Sutton. 1996. Assessment of Progress in Selected Water Quality Projects of USDA and State Cooperators. Washington, DC: USDA Natural Resources Conservation Service Quality Management and Program Evaluation Division.

MPCA (Minnesota Pollution Control Agency). 2003. Volunteer Surface Water Monitoring Guide. St. Paul, MN: Minnesota Pollution Control Agency. https://www.pca.state.mn.us/water/ volunteer-surface-water-monitoring-guide.

Morrison, J., and J. Lake. 1983. Environmental Impact of Land Use on Water Quality Black Creek Project-Final Report. Fort Wayne, IN: Allen County Soil and Water Conservation District.

Olsen, A.R., and D.M. Robertson. 2003. Monitoring design. Water Resources Impact 5(5):14-16.

Osmond. D., D. Meals, D. Hoag, and M. Arabi. 2012. How to Build Better Agricultural Conservation Programs to Protect Water Quality: The National Institute of Food and Agriculture-Conservation Effects Assessment Project Experience. Ankeny, IA: Soil and Water Conservation Society.

Richards, P.R., and D.B. Baker. 2002. Trends in water quality in LEASEQ rivers and stream (Northwester Ohio), 1975-1995. Journal of Environmental Quality 31:90-96.
Scott, E.M., and J.C. Gemmell. 2013. Water quality assessment and European water framework directive. In Encyclopedia of Environmetrics, eds.A.H El-Shaarawi and W.W. Piegorsch. Chichester, West Sussex: Wiley.

Schnepf, M., and C. Cox. 2006. Environmental Benefits of Conservation on Cropland: The Status of our Knowledge. Ankeny, IA: Soil and Water Conservation Society.

Sharpley, A.N., T.C. Daniel, G. Gibson, L. Bundy, M. Cabrera, J.T. Sims, R. Stevens, J. Lemunyon, P.J.A. Kleinman, and R. Parry. 2006. Best Management Practices to Minimize Agricultural Phosphorus Impacts on Water Quality. USDA Agricultural Research Service Publication 163. Washington, DC: US Government Printing Office.

Shepard, R. 2005. Nutrient management planning: Is it the answer to better management? Journal of Soil and Water Conservation 60(4):171-176.

Smith, T.A., D.L. Osmond, and J.W. Gilliam. 2006. Riparian buffer width and nitrate removal in a lagoon-effluent irrigated agricultural area.Journal of Soil and Water Conservation 61(5):273-281.

Spooner, J., and D.E. Line. 1993. Effective monitoring strategies for demonstrating water quality changes from nonpoint source controls on a watershed scale. Water Science and Technology 28:143-148.

Spooner,J., D.E. Line, D. Meals, G.L. Grabow, and D.L. Osmond. 2011. Summary Report: Section 319 National Monitoring Program Projects. Raleigh, NC: Nonpoint Source Watershed Project Studies, Water Quality Group, Biological and Agricultural Engineering Department, North Carolina State University. https://319monitoring. wordpress.ncsu.edu/states-with-projects/ summary-report-full-report/.

Tomer, M.D., and M.A. Locke. 2011. The challenge of documenting water quality benefits of conservation practices: A review of USDAARS's Conservation Effects Assessment Project Watershed Studies. Water Science and Technology 64:300-310, doi:10.2166/wst.2011.555.

Tomer, M.D. E.J. Sadler, R.E. Lizotte, R.B. Bryant, T.L. Potter, M.T. Moore, T.L. Veith, C. Baffaut, M.A. Locke, and M.R. Walbridge. 2014.A decade of conservation effects assessment research by the USDA Agricultural Research Service: Progress overview and future outlook. Journal of Soil and Water Conservation 69(5):365-373.

USDA NRCS (USDA Natural Resources Conservation Service). 2003. National Water Quality Handbook. Washington, DC: USDA Natural Resources Conservation Service. http://www.nrcs.usda.gov/Internet/FSE_ DOCUMENTS/stelprdb1044775.pdf.
USDA NRCS. 2012a. Conservation Practice Standard, Edge-Of-Field Water Quality Monitoring Data Collection and Evaluation Conservation Activity 201. Washington, DC: USDA Natural Resources Conservation Service. http://www.nrcs.usda.gov/Internet/FSE_ DOCUMENTS/stelprdb1097617.pdf.

USDA NRCS. 2012b. Conservation Practice Standard, Edge-Of-Field Water Quality Monitoring Installation Conservation Activity 202. Washington, DC: USDA Natural Resources Conservation Service. http://www.nrcs.usda.gov/Internet/FSE_ DOCUMENTS/stelprdb1097618.pdf.

USEPA (US Environmental Protection Agency). 1997. Volunteer Stream Monitoring: A Methods Manual. EPA 841-B-97-003. Washington, DC: US Environmental Protection Agency. https:// www.epa.gov/sites/production/files/2015-06/ documents/stream.pdf.

USEPA. 2006. Elements of a State Water Monitoring and Assessment Program. EPA 841-B-03-003. Washington, DC: US Environmental Protection Agency. https://archive.epa.gov/water/archive/ web/html/statemonitoring.html.

USEPA. 2008. Hypoxia in the Northern Gulf of Mexico:An Update by the EPA Science Advisory Board. EPA-SAB-08-003. Washington, DC: US Environmental Protection Agency.

USEPA. 2013. Nonpoint Source Program and Grants Guidelines for States and Territories. Washington, DC: US Environmental Protection Agency. https:// www.epa.gov/sites/production/files/2015-09/ documents/319-guidelines-fy14.pdf.

USEPA. 2016. Nonpoint Source Success Stories. Washington, DC: US Environmental Protection Agency. https://www.epa.gov/nps/ nonpoint-source-success-stories.

Van Meter, K.J., N.B. Basu, J.J. Veenstra and C.L. Burras. 2016. The nitrogen legacy: Emerging evidence of nitrogen accumulation in anthropogenic landscapes. Environmental Research Letters 11(3).

Ward, A.D., J.L. Hatfield, J.A. Lamb, E.E. Alberts, T.J. Logan, and J.L. Anderson. 1994. The management systems evaluation areas program: Tillage and water quality research. Soil and Tillage Research 30(1):49-74, doi: 10.1016/0167-1987(94)90150-3.

Ward, R.C., J.C. Loftus, and G.B. McBride. 1990. Design of Water Quality Monitoring Systems. Hoboken, NJ:Wiley.

Williams, M.R., K.W. King,W. Ford, and N.R. Fausey. 2016. Edge-of-field research to quantify the impacts of agricultural practices on water quality in Ohio. Journal of Soil and Water Conservation 71(1):9A-12A, doi: 10.2489/jswc.71.1.9A. 